\title{
BRONCHIAL HYPERRESPONSIVENESS IN WOMEN COOKS AND CLEANERS
}

\author{
Jovanka KARADŽINSKA-BISLIMOVSKA, Jordan MINOV, Snežana RISTESKA-KUC, Sašo \\ STOLESKI, and Dragan MIJAKOSKI \\ Institute of Occupational Health-WHO Collaborating Center, Skopje, R. Macedonia
}

Received in February 2007

Accepted in March 2007

\begin{abstract}
The aim of this cross-sectional study was to assess the prevalence and characteristics of bronchial hyperresponsiveness (BHR) in 43 women cleaners (aged 26 to 57) and 37 women cooks (aged 29 to 55) and compare them with 45 controls (women office workers aged 27 to 58). The evaluation of all subjects included a questionnaire, skin prick tests to common aeroallergens, spirometry, and histamine challenge (PC20 $\leq 8 \mathrm{mg} \mathrm{mL}^{-1}$ ). We found higher BHR prevalence in cleaners and cooks than in office workers $(30.2 \%$ and $29.7 \%$, vs. $17.7 \%$, respectively), but statistical significance was not reached. The prevalence of mild and moderate to severe BHR was similar in all groups. Borderline BHR prevalence was significantly higher in cleaners than in controls $(16.2 \%$ vs. $6.6 \%, P=0.032)$ whereas the difference was on the verge of significance in cooks ( $13.5 \%$ us. $6.6 \%, \mathrm{P}=0.081)$. Moderate to severe $\mathrm{BHR}$ was strongly associated with positive family history of asthma and atopy in all groups. Mild BHR was significantly associated with daily smoking in cleaners $(P=0.031)$ and cooks $(P=0.021)$, as well as with the duration of exposure in cleaners $(\mathrm{P}=0.038)$. Borderline $\mathrm{BHR}$ was closely related to daily smoking and duration of exposure in both cleaners and cooks. Our findings indicate an important role of workplace exposure in borderline BHR development, as well as the significant effect of smoking on mild BHR development in women cleaners and cooks.
\end{abstract}

KEY WORDS: bronchial provocation tests, occupational exposure, smoking

Bronchial hyperresponsiveness (BHR) refers to an exaggerated response to a bronchoconstrictor. Bronchoconstrictors include pharmacological agents, non-isotonic aerosols, cold air, exercise, allergens and occupational sensitisers (1).

BHR is characteristic of both asthma and chronic obstructive pulmonary disease (COPD) (2). It appears to be associated with inflammatory disorders in the airways in both diseases. On the other hand, there is evidence that an unbalance between the sympathetic and parasympathetic system with vagal preponderance could also play a role (3). Although BHR is not specific for asthma, nearly all patients with asthma exhibit increased responsiveness, which is more marked during symptomatic episodes (4). BHR of lower intensity than in asthma is present in a majority of patients with mild to moderate COPD (5).
BHR may occur in the course of other diseases, such as allergic rhinitis, atopic dermatitis, cystic fibrosis, and congestive heart failure, and its prevalence in the general population varies from $10 \%$ to $20 \%$. (4).

Results from several studies showed a higher BHR prevalence in women than in men (6-9). In some studies, sex difference was explained by the difference in airway geometry between men and women, while in other studies the prevalence of BHR remained higher in women, even after adjustment for airway calibre (68). Other mechanisms responsible for higher airway susceptibility to non-specific stimuli in women include body height (adult men are taller than women), greater cholinergic irritability, and hormonal factors (9).

A number of epidemiological studies support the view that workplace exposure to air pollutants is associated with a broad spectrum of adverse 
respiratory effects in vulnerable individuals (10). There is a growing interest about the role of occupational exposure (e.g. to mineral or organic dust, gases, fumes, and vapours) in BHR development. Nevertheless, the relation between workplace exposure and BHR in women cooks and cleaners has only been investigated sporadically.

\section{SUBJECTS AND METHODS}

\section{Study design}

A cross-sectional study was carried out at the Institute of Occupational Health, Skopje -WHO Collaborative Center (IOH-WHO) from June 2004 to January 2006. The prevalence and the characteristics of BHR were evaluated in women cooks and cleaners, and compared to unexposed women who served as controls.

\section{Subjects}

The exposed groups included 80 women cooks and cleaners. The group of professional cleaners consisted of 43 women (aged 26 to 57) whose work shift was eight hours a day and their workplace exposure included a variety of high- and low-molecular weight sensitizers and irritants from a variety of cleansing agents (detergents, antiseptics, disinfectants). According to the classification of occupations by the European Community Respiratory Health Survey (ECRHS), cleaning belongs to the occupational set "Cleaners" (11).

The group of professional cooks included 37 women (aged 29 to 55) working in restaurants and using gas appliances. Their work shift was also eight hours a day, and their workplace exposure included combustion products $\left(\mathrm{NO}_{2}\right.$ ), as well as many sensitizers and irritants of herbal (tomato, onion, garlic, etc.) and animal origin (meat, poultry, fish, etc). According to the ECRHS classification, cooking belongs to the occupational set "Other food processors".

In addition, 45 unexposed women (office workers aged 27 to 58) were studied as controls. Controls belonged to the ECRHS occupational set "Remainder professional, administrative, clerical, service".

Neither group included subjects in whom histamine challenge was contraindicated $(12,13)$ or subjects with the upper respiratory viral infection within three weeks before the challenge test. None of the subjects took asthma medications or antihistamines at least one month before the challenge test and skin-prick test.

\section{Questionnaire}

All subjects were interviewed by a physician who filled in the questionnaire. Respiratory symptoms in the last 12 months (cough, phlegm, dyspnoea, wheezing, and chest tightness) were documented using the European Community for Coal and Steel questionnaire (ECCS-87), and the ECRHS questionnaire $(14,15)$.

Detailed smoking history, family history of asthma (taking into account the first-degree relatives), accompanying disease, and medication use were also evaluated.

Smoking was classified according to the World Health Organization (WHO) guidelines on definitions of smoking status (16). A "daily smoker" was defined as a subject who smoked at least once a day at the time of the survey, except on days of religious fasting. In daily smokers we evaluated lifetime cigarette smoking ( $\leq 5,6$ to 10,11 to 20 , and $\geq 21$ ) years and daily mean of cigarettes smoked ( $\leq 10,11$ to 20 , and $\geq 21$ ). An "ex-smoker" was defined as a former daily smoker who no longer smokes. Passive smoking or exposure to environmental tobacco smoke (ETS) was defined as the exposure of a person to tobacco combustion products from smoking by others (17).

\section{Skin prick tests}

Skin prick tests (SPT) to common inhalant allergens were performed in all subjects by the $\mathrm{IOH}$ WHO Allergy Center on the volar part of the forearm, using commercial allergen extracts (Torlak, Serbia and Montenegro) of birch (5000 PNU), mixed grass (5000 PNU), plantain (5000 PNU), mixed fungi (4000 PNU), Dermatophagoides pteronyssinus (3000 PNU), dog hair (4000 PNU), cat fur (4000 PNU), and mixed feathers (4000 PNU). All tests included positive (1 $\mathrm{mg} \mathrm{mL}^{-1}$ histamine) and negative $(0.9 \%$ saline) controls. The tests were considered positive if the mean wheal diameter 20 min after allergen application was at least $3 \mathrm{~mm}$ larger than the size of the negative control (18). Atopy was defined as the presence of at least one positive SPT (19).

\section{Spirometry}

Spirometry, including measurements of forced vital capacity (FVC), forced expiratory volume in 
one second $\left(\mathrm{FEV}_{1}\right), \mathrm{FEV}_{1} / \mathrm{FVC}$ ratio, and maximal expiratory flow at $50 \%, 25 \%$, and $25-75 \%$ of FVC $\left(\mathrm{MEF}_{50}, \mathrm{MEF}_{25}\right.$, and $\mathrm{MEF}_{25-75}$, respectively), was performed in all subjects at the IOH-WHO Department of Cardiorespiratory Functional Diagnostics using spirometer Ganshorn SanoScope LF8 (Ganshorn Medizin Electronic GmbH, Germany). We recorded the best of three reproducible measurements. The results of spirometry were expressed as percentages of predicted values set by the ECCS norms (20).

\section{Histamine challenge}

The histamine challenge was performed in all subjects at the $\mathrm{IOH}-\mathrm{WHO}$ Department of Cardiorespiratory Functional Diagnostics according to the European Respiratory Society (ERS)/American Thoracic Society (ATS) recommendations $(12,13)$. Concentrations of $0.5 \mathrm{mg} \mathrm{mL}^{-1}, 1 \mathrm{mg} \mathrm{mL}^{-1}, 2 \mathrm{mg}$ $\mathrm{mL}^{-1}, 4 \mathrm{mg} \mathrm{mL}^{-1}$, and $8 \mathrm{mg} \mathrm{mL}^{-1}$ histamine (Torlak, Serbia and Montenegro) were prepared by dilution with buffered saline. Aerosol doses generated by Pari LC nebulizer (Pari GmbH, Germany) were inhaled through a mouthpiece. The subjects inhaled increasing concentrations of histamine using a tidal breathing method until $\mathrm{FEV}_{1}$ fell by more than $20 \%$ of its base value (provocative concentration 20 - PC20) or the highest concentration was reached.

According to the ATS recommendations bronchial hyperresponsiveness (BHR) was categorised as moderate to severe BHR (PC20<1.0 $\left.\mathrm{mg} \mathrm{mL}^{-1}\right)$, mild BHR (PC20 =1.0-4.0 $\mathrm{mg} \mathrm{mL}^{-1}$ ), and borderline BHR (PC20>4.0 $\mathrm{mg} \mathrm{mL}^{-1}$ ). The test was considered positive if PC20 was equal or less than $4 \mathrm{mg} \mathrm{mL}^{-1}(13)$.

\section{Statistical analysis}

Continuous variables were expressed as mean values with standard deviation (SD) and nominal variables as numbers and percentages. The chi-square test (or Fisher's exact test where appropriate) was used for testing difference in prevalence. Spirometry measurements and PC20 values were compared using the independent-samples $t$-test. The chi-square test (or Fisher's exact test where appropriate) was also used for testing the association between BHR and studied variables, such as family history of asthma, atopy, baseline $\mathrm{FEV}_{1}$ (less or more than $80 \%$ of the predicted value), body mass index (BMI, less or more than 25), daily, ex-, and passive smoking, as well as exposure duration in the exposed workers (less or more than 10 years). Mann-Whitney ( $I$-test was used for testing the association between BHR in daily smokers and smoking experience or daily cigarette consumption. A P-value below 0.05 was considered statistically significant. Statistical analysis was performed using the Statistical Package for the Social Sciences (SPSS) version 11.0 for Windows.

\section{RESULTS}

Characteristics of the subjects enrolled in the study are given in Table 1. Respiratory symptoms in the last 12 months were higher in the exposed workers, with a significant difference for phlegm ( $\mathrm{P}=0.019$; Fisher's exact test) and dyspnoea ( $\mathrm{P}=0.041$; Fisher's exact test) in cleaners and for phlegm in cooks $(P=0.029$; Fisher's exact test) (Table 2).

The prevalence of atopy in cooks, cleaners, and office workers was similar $(35.1 \%, 32.5 \%$, and $29.1 \%$, respectively). Mite sensitisation was the most important common aeroallergen in all occupation groups (18.9\%, $20.9 \%$, and $17.7 \%$, respectively).

All mean spirometric parameters were significantly lower in the exposed workers than in controls (Table 3).

The prevalence of BHR was higher in cooks and cleaners than in office workers, but statistical significance was not reached (Figure 1). The mean PC20 was similar in all occupation groups (Figure 2). The prevalence of moderate to severe and mild BHR was similar in all occupation groups. The prevalence of borderline BHR was significantly higher in cleaners than in controls ( $16.2 \%$ vs. 6.6 \%, P=0.032; Fisher's exact test), whereas its prevalence in cooks was also higher than in controls, but not significantly (13.5\% us. $6.6 \%, P=0.081$; Fisher's exact test) (Figure 3).

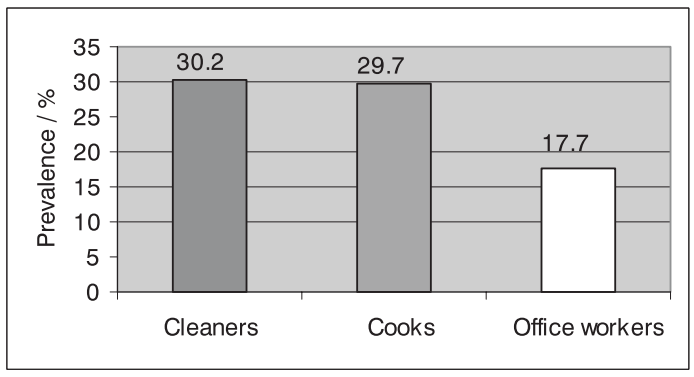

Figure 1 Prevalence of BHR in cleaners, cooks, and office workers. Nonsignificant difference in the BHR prevalence between certain occupation groups. BHR: bronchial hyperresponsiveness. 


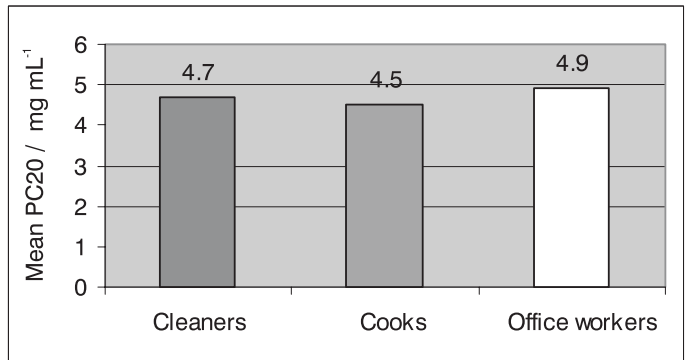

Figure 2 Mean PC20 in cleaners, cooks, and office workers: cleaners $\left(4.7 \pm 3.7 \mathrm{mg} \mathrm{mL}^{-1}\right)$, cooks $(4.5 \pm 3.7) \mathrm{mg} \mathrm{mL}^{-1}$, office workers $(4.9 \pm 3.1) \mathrm{mg} \mathrm{mL}^{-1}$. Non-significant difference in the BHR prevalence between certain occupation groups. PC20: provocative concentration 20; BHR: bronchial hyperresponsiveness.

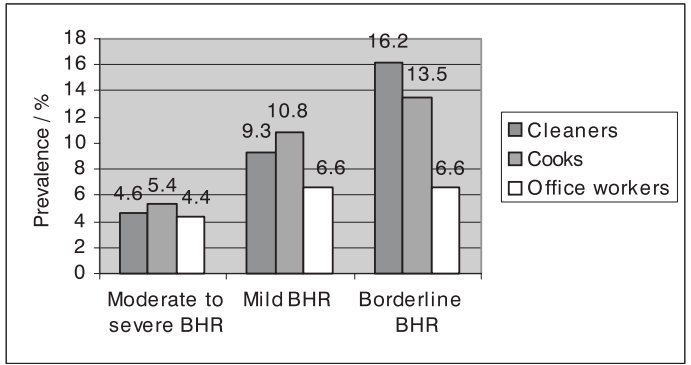

Figure 3 Prevalence of BHR categories in cleaners, cooks, and office workers. BHR: bronchial hyperresponsiveness.

Table 1 Characteristics of the examined subjects

\begin{tabular}{lccc}
\hline Variable & $\begin{array}{c}\text { Cleaners } \\
(\mathbf{n}=43)\end{array}$ & $\begin{array}{c}\text { Cooks } \\
(\mathbf{n}=37)\end{array}$ & $\begin{array}{c}\text { Office workers } \\
(\mathbf{n}=45)\end{array}$ \\
\hline Age / years & $36.8 \pm 7.5$ & $39.6 \pm 6.9$ & $38.1 \pm 5.7$ \\
BMI / kg m ${ }^{-2}$ & $24.7 \pm 3.9$ & $26.4 \pm 4.2$ & $25.7 \pm 3.8$ \\
Duration of employment / years & $14.1 \pm 6.2$ & $16.3 \pm 4.8$ & $15.9 \pm 5.3$ \\
Duration of exposure / years & $11.6 \pm 5.5$ & $13.9 \pm 5.7$ & $/$ \\
Positive family history of asthma & $3(6.9 \%)$ & $3(8.1 \%)$ & $4(8.8 \%)$ \\
Daily smokers & $10(23.2 \%)$ & $10(27.0 \%)$ & $12(26.6 \%)$ \\
Smoking experience / years & $11.9 \pm 4.7$ & $13.8 \pm 3.1$ & $14.3 \pm 5.8$ \\
Cigarettes per day & $15.8 \pm 7.4$ & $13.1 \pm 4.6$ & $12.4 \pm 5.3$ \\
Ex-smokers & $3(6.9 \%)$ & $2(5.4 \%)$ & $5(11.1 \%)$ \\
Passive smokers & $7(16.2 \%)$ & $5(13.5 \%)$ & $8(17.7 \%)$ \\
\hline
\end{tabular}

Numerical data are expressed as mean value with standard deviation; the frequencies of positive family history of asthma, daily, ex-, and passive smokers as number and percentage of examinees with certain variable.

M: male; F: female; BMI: body mass index

Table 2 Respiratory symptoms in the last 12 months in the examined subjects

\begin{tabular}{|c|c|c|c|}
\hline $\begin{array}{l}\text { Respiratory symptoms in the last } 12 \\
\text { months }\end{array}$ & $\begin{array}{l}\text { Cleaners } \\
(n=43)\end{array}$ & $\begin{array}{l}\text { Cooks } \\
(n=37)\end{array}$ & $\begin{array}{l}\text { Office workers } \\
(n=45)\end{array}$ \\
\hline Any respiratory symptom & $15(34.9 \%)$ & $12(32.4 \%)$ & $11(24.4 \%)$ \\
\hline Cough & $9(20.9 \%)$ & $7(18.9 \%)$ & $7(15.5 \%)$ \\
\hline Phlegm & $7(16.3 \%)$ & $6(16.2 \%)$ & $2(4.4 \%)$ \\
\hline Dyspnea & $8(18.6 \%)$ & $5(13.5 \%)$ & $4(8.8 \%)$ \\
\hline Wheezing & $7(16.3 \%)$ & $5(13.5 \%)$ & $5(11.1 \%)$ \\
\hline Chest tightness & $5(11.6 \%)$ & $5(13.5 \%)$ & $4(8.8 \%)$ \\
\hline
\end{tabular}

Data are expressed as number and percentage of examinees with certain variable.

Moderate to severe BHR was significantly associated with family history of asthma and atopy in all groups. The association with other tested variables, such as duration of exposure in the exposed workers, baseline $\mathrm{FEV}_{1}, \mathrm{BMI}$, and daily, ex- and passive smoking, was not statistically significant in any of the groups.
Mild BHR was significantly related to the baseline lung function in all groups. Positive association with atopy was detected in cooks $(P=0.028$; Fisher's exact test) and controls ( $P=0.036$; Fisher's exact test). Mild BHR in cleaners was significantly related to daily smoking and duration of exposure $(\mathrm{P}=0.031$; 
Table 3 Spirometric parameters in the examined subjects

\begin{tabular}{lccc}
\hline Spirometric parameter & $\begin{array}{c}\text { Cleaners }(n=43) \\
\text { Mean } \pm \text { SD }\end{array}$ & $\begin{array}{c}\text { Cooks }(n=37) \\
\text { Mean } \pm \text { SD }\end{array}$ & $\begin{array}{c}\text { Office workers }(n=45) \\
\text { Mean } \pm \text { SD }\end{array}$ \\
\hline FVC / \%pred & $88.2 \pm 13.2$ & $91.8 \pm 14.7$ & $104.8 \pm 10.1$ \\
$\mathrm{FEV}_{1} /$ \%pred & $81.4 \pm 8.9$ & $84.1 \pm 10.2$ & $96.1 \pm 6.7$ \\
$\mathrm{FEV}_{1} / \mathrm{FVC} / \%$ & $71.4 \pm 3.1$ & $73.1 \pm 5.2$ & $79.6 \pm 3.8$ \\
$\mathrm{MEF}_{50} / \%$ pred & $62.9 \pm 9.8$ & $67.9 \pm 13.6$ & $82.6 \pm 12.7$ \\
$\mathrm{MEF}_{25} / \%$ pred & $54.3 \pm 11.1$ & $58.1 \pm 14.2$ & $74.8 \pm 10.9$ \\
$\mathrm{MEF}_{25-75} / \%$ pred & $72.1 \pm 12.6$ & $78.6 \pm 14.8$ & $91.7 \pm 13.4$ \\
\hline
\end{tabular}

FVC: forced vital capacity; $\mathrm{FEV}_{1}$ : forced expiratory volume in one second; $\mathrm{MEF}_{50}, \mathrm{MEF}_{25}, \mathrm{MEF}_{25-75}$ : maximal expiratory flow at $50 \%, 25 \%$ and $25-75 \%$ of FVC, respectively; $\%$ pred: \% of predicted value.

Fisher's exact test, and $\mathrm{P}=0.038$; Fisher's exact test, respectively), and in cooks significant association was found with daily smoking $(\mathrm{P}=0.021$; Fisher's exact test). The association with smoking experience was significant in both cleaners ( $\mathrm{P}=0.024$; Mann-Whitney $U$-test) and cooks ( $\mathrm{P}=0.029$; Mann-Whitney $U$-test), whereas the association with cigarettes smoked per day was significant in cleaners $(P=0.043$; MannWhitney (I-test).

Borderline BHR was strongly associated with baseline $\mathrm{FEV}_{1}$, daily smoking, and smoking experience in all groups, as well as with exposure duration in the exposed groups. The association with cigarettes smoked per day was significant in cleaners $(P=0.019$; Mann-Whitney (I-test).

\section{DISCUSSION}

Workplace exposure to dusts, fumes, vapours, or gases is a well-known risk factor for respiratory impairment. In a cross-sectional study including 3,044 never smokers from eight areas in Switzerland, Leuenberger et al. (21) reported that metacholine slopes were $19 \%$ (95\% CI 6-32) higher for never smokers with workplace exposure to dusts, fumes, vapours, or gases than for unexposed controls. On the other hand, women are considered more vulnerable to BHR and lung function impairment than men (6-9).

Over the last decade, several studies have examined the effects of occupational exposure of cooks and cleaners of both sexes, producing somewhat inconsistent results (22-25). In our study, all occupation groups (cooks, cleaners, and control office workers) consisted of subjects with similar demographic characteristics. In all groups there was a large proportion of daily and passive smokers that was similar to industrial workers documented in our previous studies (26).

We found a significantly higher prevalence for phlegm in both exposed groups and for dyspnoea in cleaners, whereas the prevalence of other symptoms (cough, wheezing, and chest tightness) was similar in all groups. Results from studies that investigated respiratory effects of similar exposure are controversial. In the Spanish contribution to the ECRHS Kogevinas et al. (11) reported a significantly higher prevalence of wheezing or whistling in cleaners than in unexposed workers. Fishwick et al. (23) reported a similar prevalence of wheezing in cleaners and unexposed workers in New Zealand. In a subsequent analysis of a combined data set from different centres included in the ECRHS, Jarvis et al. (27) reported that the association between gas cooking and respiratory symptoms in women varied considerably from centre to centre. These differences could be related to differences in cleansing agents and gas between the countries.

The prevalence of atopy and the pattern of allergic sensitisation in both exposed and unexposed subjects was comparable to what we observed earlier among adults in Macedonia (28). Spirometric parameters were lower in the exposed workers, confirming that exposure to dusts, fumes, vapours, or gases is associated with chronic airflow obstruction, predominantly affecting the smaller airways (29). Žuškin et al. (30) and Wang et al. (31) reported similar findings in studies with exposed women workers (latex glove manufacturers and cotton textile workers). Jarvis et al. (32) reported that women who used gas cookers had an increased risk of lower lung function $\left(\mathrm{FEV}_{1}\right.$ and $\left.\mathrm{FEV}_{1} / \mathrm{FVC}\right)$ than women not using gas cookers, whereas no such association was found in men. 
We found a higher prevalence of BHR detected by histamine challenge $\left(\mathrm{PC} 20 \leq 8 \mathrm{mg} \mathrm{mL}^{-1}\right)$ in cooks and cleaners, but it was not statistically significant. Fishwick et al. (23) reported a similar prevalence of BHR (detected by metacholine challenge, cumulative dose of $1 \mathrm{~g}$ ) in cleaners of both sexes compared to unexposed subjects (OR=0.62 $95 \% \mathrm{Cl} 0.19$ to 2.05$)$. The prevalence of moderate to severe and mild BHR was similar in all groups in our study. Borderline BHR prevalence was higher in the exposed women, with statistical significance in cleaners, confirming the findings of Dimich-Ward et al. (33) that workplace exposure to dusts, fumes, vapours, and gases may lead to the development of chronic airway obstruction independent of cigarette smoking and specific exposure effects such as asthma, hypersensitivity pneumonitis or pneumoconiosis.

Moderate to severe BHR, which is common in chronic inflammation in asthmatic airways, was closely related to family history of asthma and atopy in all groups, confirming its role in asthma development (34).

The results from the studies that have analysed the association between BHR and smoking are controversial. Some found daily smoking to be independent of BHR $(6,35)$ others, such as Sunyer et al. (36), found that smoking was associated with BHR only in non-atopic subjects, while Leynaert et al. (7) reported that heavy smoking women had an increased risk of mild to moderate BHR, but no such association was found in men. A 10 year follow-up carried out in the US on a large sample of women $(74,072)$ showed that daily smokers had a lower risk of developing asthma than never- and ex-smokers (37). On the other hand, Janson et al. (22) and Paoletti et al. (9) indicated that daily smoking may have different importance in different BHR categories. We found no association between moderate to severe BHR and daily smoking, but the association between mild BHR and daily smoking was significant in the exposed groups and non-significant in office workers. The association between borderline BHR and daily smoking was significant in all groups. Paoletti et al. (9) suggest that women exhibit a dose-response relationship between daily cigarette consumption and BHR; a result not observed in men. This study shows a significant association between mild and borderline BHR and daily cigarette consumption.

Finally, we found a non-significant association of exposure duration with moderate to severe BHR, significant association with mild BHR in cleaners, and significant association with borderline BHR in both exposed groups. The significant association between daily smoking and mild BHR observed in the exposed groups and no such association in office workers suggests that workplace exposure and smoking additively contribute to the development of mild BHR and lung function impairment, but we have found no confirmation of this in literature. Studying male farming students, Omland et al. (38) reported additional effect of exposure to farming and daily smoking in BHR development. In contrast, Zock et al. (39) reported a non-significant association in young adults of both sexes with workplace exposure to dust, vapours, gases or fumes in 14 industrialised countries. However, respiratory effects of the tobacco smoke may vary in subjects with different exposures at workplace.

The limitation of our study is a relatively small number of subjects, which may has certain implications about the data obtained and their interpretation. Furthermore, as we did not perform environmental measurements at the workplaces, we could not document the level of exposure and estimate its association with BHR. At the time of the study, we also did not have standardised workplace allergens for the exposed groups to establish sensitisation and their association with BHR.

In conclusion, we found higher BHR prevalence in women cooks and cleaners, but statistical significance was not reached. The prevalence of mild and moderate to strong BHR was similar in all groups, while borderline BHR was more frequent in the exposed workers, with statistical significance for cleaners. Moderate to severe BHR was significantly associated with family history of asthma and atopy in all groups. Mild BHR was significantly associated with exposure duration in cleaners, and with daily smoking in both cooks and cleaners. Borderline BHR was significantly associated with exposure duration and daily smoking in both exposed groups. Our study confirms the need for regular medical examination in order to identify affected workers and institute preventive measures. It also underlines the need for more effective tobacco control measures that will prevent respiratory adverse effects produced by combined tobacco smoke and workplace exposure.

\section{REFERENCES}

1. Sterk PJ, Bel EH. Bronchial hyperresponsiveness: the need for a distinction between hypersensitivity and 
excessive airway narrowing. Eur Respir J 1989;2:26774.

2. Joos GF, O'Connor B. Indirect airway challenge. Eur Respir J 2003;21:1050-68.

3. Saric M. Bronchial hyperreactivity and occupational asthma (Editorial). Am J Ind Med 1986;9:217-219.

4. Bel EH, Chanez P. Diagnosis and assessment of asthma. Eur Respir Mon 2003;8:180-94.

5. Tashkin DP, Alose MD, Bleecker ER, Connett JE, Kanner RE, Lee WW, Wise R. The lung health study: airway responsiveness to inchalant metacholine in smokers with mild to moderate airway limitation. Am Rev Respir Dis 1992;145:301-10.

6. Norrman E, Plashcke P, Bjornsson E, Rosenhall L, Lundback B, Jansson C, Llindholm N, Boman G. Prevalence of bronchial hyperresponsiveness in the southern, central and northern parts of Sweden. Respir Med 1998;92:480-7.

7. Leynaert B, Bousquet J, Henry C, Liard R, Neukirch F. Is bronchial hyperresponsiveness more frequent in women than in men? A population-based study. Am J Respir Crit Care Med 1997;156:1413-20.

8. Wassmer G, Jorres RA, Heinrich J, Wjst M, Reitmeir P, Wichmann HE. The association between baseline lung function and bronchial responsiveness to metacholine. Eur J Med Res 1997;2:47-54.

9. Paoletti P, Carrozzi L, Viegi G, Modena P, Ballerin L, Di Pede F, Grado L, Baldacci S, Pedreschi M, Vellutini M, Paggiaro P, Mammini U, Fabbri L, Giuntini C. Distribution of bronchial responsiveness in a general population: effect of sex, age, smoking, and level of pulmonary function. Am J Respir Crit Care Med 1995;151:1770-9.

10. Cacciola RR, Sarva M, Polosa R. Adverse respiratory effects and allergic susceptibility in relation to particulate air pollutants: flirting with disaster. Allergy 2002;57:281-6.

11. Kogevinas M, Anto JM, Soriano JB, Tobias A, Burney $P$, and the Spanish Group of the European Asthma Study. The risk of asthma attributable to occupational exposures: a population-based study in Spain. Am J Respir Crit Care Med 1996;154:137-43.

12. Sterk PJ, Fabbri LM, Quanjer PhH, Cockcroft DW, O'Byrne PM, Anderson SD, Juniper EF, Malo JL. Airways responsiveness. Standardized challenge testing with pharmacological, physical and sensitizing stimuli in adults. Eur Respir J 1993;6:58-83.

13. American Thoracic Society. Guidelines for metacholine and exercise challenge testing -1999. Am Respir Crit Care Med 2000;161:309-29.

14. Minette A. Questionnaire of the European Community for Coal and Steel (ECSC) on respiratory symptoms. 1987 - updating of the 1962 and 1967 questionnaires for studying chronic bronchitis and emphysema. Eur Respir J 1989;2:165-77.

15. European Community Respiratory Health Survey.
Variations in the prevalence of respiratory symptoms, self-reported asthma attacks, and use of asthma medication in the European Respiratory Health Survey (ECRHS). Eur Respir J 1996;9:687-95.

16. World Health Organization (WHO). Guidelines for controlling and monitoring the tobacco epidemic. Geneva: WHO; 1998.

17. US Department of Health and Human Services. The health consequences of smoking: chronic obstructive pulmonary disease. A report of the Surgeon General. US Department of Health and Human Services, Public Health Service, Office of the Assistant for Health, Office of Smoking and Health. DHHS Publication No. 84-50 205, 1984

18. The European Academy of Allergology and Clinical Immunology. Position paper: Allergen standardization and skin tests. Allergy 1993;48(Suppl 14):48-82.

19. Frew AJ. Allergic basis of asthma. Eur Respir Mon 2003;23:74-83.

20. Quajner PhH, editor. Standardization of Lung Function Tests - 1993 Update. Report Working Party for the European Community for Steel and Coal. Official Statement of the European Respiratory Society. Eur Respir J 1993;16 Suppl:1-100.

21. Leuenberger P, Schnidler C, Schwartz J, AckermannLiebrich U, Tara D, Perruchoud AP, Wuthrich B, Zellweger JP, Blaser K, Bolognini G, Bongrad JP, Brandli O, Domenighetti G, Elsasser S, Grize L, Karrer W, Keiler R, Kunzli N, Medici T, Schoni MH, Solari G, Tschopp JM, Villiger B, Zemp E. Occupational exposure to inhalative irritants and metacholine responsiveness. Scand J Work Environ Health 2000;26:146-52.

22. Janson C, Anto J, Burney P, Chinn S, de Marco R, Heinrich J, Jarvis D, Kuenzli N, Leynaert B, Luczynska C, Neukirch F, Svanes C, Sunyer J, Wjst M, on behalf of the European Community Respiratory Health Survey II. The European Community Respiratory Health Survey: what are the main results so far? Eur Respir $\mathrm{J}$ 2001;18:598-611.

23. Fishwick D, Pearce N, D'Souza W, Lewis S, Town I, Armstrong R, Kogevinas M, Crane J. Occupational asthma in New Zealanders: a population based study. Occup Environ Med 1997;54:301-6.

24. Brunekreef $\mathrm{B}$. $\mathrm{NO}_{2}$ : The gas that won't go away. Clin Exp Allergy 2001;31:1170-2.

25. Willers SM, Brunekreef B, Oldenwening M, Smith HA, Kerkhof $M$, Vries $H$. Gas cooking, kitchen ventilation, and exposure to combustion products. Indoor Air 2006;16:65-73.

26. Minov J, Karadzinska-Bislimovska J, Risteska-Kuc S, Stoleski S. Chronic respiratory symptoms and ventilatory function in workers exposed to tea dust: effect of duration of exposure and smoking. Facta Universitatis 2005;12:37-43

27. Jarvis D, Chinn S, Sterne J, Luczynska C, Burney P. The association of respiratory symptoms and lung 
function with the use of gas for cooking. Eur Respir $\mathrm{J}$ 1998;11:651-8.

28. Karadzinska-Bislimovska J, Cvetanov V, Petrovska J, Todorov S, Risteska-Kuc S. Respiratory symptoms and positive skin prick test in a prospective asthma study in Republic of Macedonia (initial results). Eur Respir J 1999;14:78.

29. Chan-Yeung M. Dimich-Ward H. Natural history of occupational lung diseases. Eur Respir Mon 1999;4:4663.

30. Zuskin E, Mustajbegovic J, Kanceljak B, Schachter EN, Macan J, Budak A. Respiratory function and immunological status in workers employed in a latex glove manufacturing plant. Am J Ind Med 1998;33:17581.

31. Wang XR, Pan LD, Zhang HX, Sun BX, Dai HL, Christiani DC. Lung function, airway reactivity, and atopy in newly hired female cotton textile workers. Arch Environ Health 2003;58:6-13.

32. Jarvis D, Chinn S, Luczynska C, Burney P. Association of respiratory symptoms and lung function in young adults with use of domestic gas appliances. Lancet 1996;347:426-31.

33. Dimich-Ward H, Kennedy SM, Chang-Yeung M. Occupational exposures and chronic airway limitation. Can Respir J 1996;3:133-40.
34. Viegi G, Annesi I, Matteelli G. Epidemiology of asthma. Eur Respir Mon 2003;8:1-25.

35. Nowak D, Heinrich J, Jorres R, Wassmer G, Berger J, Beck E, Boczor S, Claussen M, Wichmann HE, Magnussen $\mathrm{H}$. Prevalence of respiratory symptoms, bronchial responsiveness, and atopy among adults: west and east Germany. Eur Respir J 1996;9:254152.

36. Sunyer J, Anto JM, Kogevinas M, Soriano JB, Tobias A, Munoz A. Smoking and bronchial responsiveness in atopic and nonatopic young adults. Thorax 1997;52:235-8.

37. Troisi RJ, Speizer FE, Rosner B, Trichopoulos D, Willett WC. Cigarette smoking and incidence of chronic bronchitis and asthma in women. Chest 1995;108:1557-61.

38. Omland O, Sigsgaard T, Pedersen OF, Miller MR. The shape of the maximum expiratory flow/volume curve reflects exposure in farming. Ann Agric Environ Med 2000;7:71-8.

39. Zock JP, Sunyer J, Kogevinas M, Kromhout H, Burney P, Anto JM. Occupation, chronic bronchitis, and lung function in young adults. An international study. Am J Respir Crit Care Med 2001;163:1572-7. 


\section{Sažetak}

\section{PRETJERANA BRONHALNA REAKTIVNOST U KUHARICA I ČISTAČICA}

Svrha je ovoga presječnog ispitivanja bila utvrditi prevalenciju i značajke pretjerane bronhalne reaktivnosti (engl. bronchial hyperresponsiveness, krat. BHR) u profesionalnih čistačica (43 ispitanice u dobi od 26 do 57 godina) i kuharica (37 ispitanica u dobi od 29 do 55 godina). Kontrolna skupina obuhvatila je 45 uredskih radnica u dobi od 27 do 58 godina. Ocjena izloženih i kontrolnih ispitanica obuhvatila je upitnik, skin prick testove na uobičajene inhalacijske alergene, spirometriju te histaminski test (PC20 $\leq 8 \mathrm{mg} \mathrm{mL}^{-1}$ ). Čistačice odnosno kuharice iskazale su veću prevalenciju BHR-a od kontrolnih uredskih radnica (30,2\% odnosno 29,7 \% prema $17,7 \%$ ), ali ona nije bila statistički značajna. Sve su skupine iskazale podjednaku prevalenciju umjerenog i snažnog BHR-a. Prevalencija graničnoga BHR-a bila je značajno viša u čistačica negoli u kontrole $(16,2 \%$ naprema $6,6 \%, P=0,032)$, a na rubu statističke značajnosti bila je i razlika između kuharica i kontrole $(13,5 \%$ prema $6,6 \%, P=0,081)$. Umjeren odnosno snažan BHR u svih je skupina bio značajno povezan s obiteljskom povijesti astme i atopija. Blagi BHR značajno je povezan sa svakodnevnim pušenjem u čistačica $(P=0,031)$ i kuharica $(P=0,021)$, a u čistačica i s trajanjem izloženosti $(P=0,038)$. Granični BHR je i u čistačica i u kuharica povezan sa svakodnevnim pušenjem i trajanjem profesionalne izloženosti. Naši podaci upućuju na važnu ulogu profesionalne izloženosti u nastanku graničnoga BHR-a te na značajan utjecaj pušenja na nastanak blagoga BHR-a u profesionalnih čistačica i kuharica.

KLJUČNE RIJEČI: bronhoprovokatiuni testovi, profesionalna izloženost, pušenje, žene

\section{CORRESPONDING AUTHOR:}

Professor Jovanka Karadzinska-Bislimovska, M.D., Ph.D. Institute of Occupational Health WHO Collaborating Center for Occupational Health II Makedonska Brigada 43,1000 Skopje, Republic of Macedonia E-mail: bislimouskaj@yahoo.com 